\title{
THE TOURIST AND TECHNICAL INFRASTRUCTURE SURVEY WITHIN THE ORADEA RURAL LEISURE METROPOLITAN BELT
}

\author{
Marcu STASAC ${ }^{*}$ \\ University of Oradea, Department of Geography, Tourism and Territorial Planning, \\ University St., 410087, Oradea, Romania, e-mail: marcu_stasac@yahoo.com
}

Marius I. STUPARIU

University of Oradea, Department of Geography, Tourism and Territorial Planning, University St., 410087, Oradea, Romania, e-mail: marius_stupariu@yahoo.co.uk

\section{Corina Florina TĂTAR}

University of Oradea, Department of Geography, Tourism and Territorial Planning, University St., 410087, Oradea, Romania, e-mail: corina_criste_78@yahoo.com

\section{Ribana LINC}

University of Oradea, Department of Geography, Tourism and Territorial Planning, University St., 410087, Oradea, Romania, e-mail: ribanalinc@yahoo.com

\section{Liviu BUCUR}

University of Oradea, Department of Geography, Tourism and Territorial Planning, University St., 410087, Oradea, Romania, e-mail: liviubucur@yahoo.com

\section{Iulian DINCĂ}

University of Oradea, Department of Geography, Tourism and Territorial Planning, University St., 410087, Oradea, Romania, e-mail: iulian_dinca@yahoo.co.uk

\section{Stelian NISTOR}

University of Oradea, Department of Geography, Tourism and Territorial Planning, University St., 410087, Oradea, Romania, e-mail: snistor@uoradea.ro

Citation: Stașac, M., Stupariu I.M., Tătar, Corina-Florina, Linc, Ribana, Bucur, L., Dincă, I., Nistor S. (2020). The Tourist and Technical Infrastructure Survey within the Oradea Rural Leisure Metropolitan Belt. Analele Universităţii din Oradea, Seria Geografie, 30(2), 182-193. https://doi.org/10.30892/auog.302108-857

\begin{abstract}
The current study is meant to be a contribution to the promotion and development of an important geographical area for the municipality of Oradea, namely the rural proximity area that is part of the Oradea Metropolitan Area (OMA). The magnitude of the tourism phenomenon, as a sustainable resource could contribute to a functional reconsideration of this space that can bring about an overall territorial development, based on economic competitiveness, sustainable development, social cohesion or the development of new technologies. In this sense, it is not possible to conceive the development of an area
\end{abstract}


from a tourist viewpoint without the existence of a suitable infrastructure (tourist, technical, transport), because it can influence, depending on the endowment degree and updated technology, the volume and structure of the tourist traffic. Thus, the main infrastructure components were identified, quantified and analyzed, each TAU being granted a certain score according to the evaluation methodology, based on which a certain hierarchy and highlighting of the main dysfunctions could be achieved. In conclusion, it was found that the existing tourist and technical infrastructure is satisfactory, but disproportionately distributed, a situation somewhat accountable due of the existence of the two spas, Băile Felix and Băile 1 Mai.

Key words: tourist infrastructure, technical infrastructure, Oradea Metropolitan Area (OMA), metropolitan rural area

$$
* \quad * \quad * \quad * \quad * \quad *
$$

\section{INTRODUCTION}

The tourist infrastructure as a component part of the general infrastructure, which, moreover, the former supports and integrates, has an overwhelming importance for a certain territory, contributing to the creation of necessary conditions for the organization of tourist services.

Starting from the importance of the tourist and technical infrastructure for a certain territory, in our case the territorial administrative units (TAU) that make up the rural area of Oradea Metropolitan Area (OMA), in this research we identified and quantified the main components of the two categories of infrastructure in order to contribute to the development of the tourist phenomenon, thus increasing the attractiveness of the rural area from the metropolitan perimeter.

Another important aim that we followed was to analyze each infrastructure-related component, at a TAU level, in order to observe the degree of their endowment, so that later a hierarchy and a highlighting of the main dysfunctions could be acomplished.

Given the economic administrative and tourist importance, this metropolitan area has been and still represents an important basis of scientific research. The tourist valences were highlighted by many researches of authors such: Dincă, 2008; Ilieș and Josan, 2009; Baias et al., 2010; Staşac and Bucur, 2010; Ilieș et al., 2011; Dincă et al., 2012; Bucur, 2012; Ilieș et al., 2013; Herman and Tătar, 2015; Dincă et al., 2017; Tătar et al., 2018; Linc et al., 2019; Herman et al., 2020; etc.

The tourist infrastructure and technical facilities has an impact on tourist development in the environs of cities, factors which were analyzed for the current study of the rural OMA. The former relates to the accommodation, restoration, cure and entertainment facilities and the technical support to transportation and communication accessibility. Among them the accommodation industry stood out in terms of statistics. Nowadays accommodation industry features a wide range of diversity and specialization (Weaver and Lawton, 2014), most predominant tourist stayovers still being in hotels followed by motels, ecolodges, timesharing, resort hotels, extended apartment hotels, villas, guesthouses, campsites; a sector which draws attention for the tourism analysts as it most often drives the largest tourist expenditure during the trip. The contemporary accommodation infrastructure adds value to the experience by providing ancillary services and products, besides that of shelter (Page, 2019). In the case of the analyzed territory of the rural OMA, resort hotels, followed by motels and guesthouses hold the largest share due to the two spas located on the rural areas of the metropolitan area, amounting to 93,3\%, showing that an old tourist consumption practically still dominates the entire rural metropolitan area, despite the huge natural (Tătar et al., 2018) and man-made tourist potential of the entire metropolitan area. As in the case of Fuschi and Evangelista's (2017) rural tourism case study, the tourist infrastructure-related results indicate that despite the great opportunity for tourism and local development, the rural area of the OMA suffers from low accommodation networking and an unbalanced accommodation facilities' distribution. It is estimated that the most of growth will take 
place in cities and their environs (Halcrow Group Ldt., 2008), with a need for relaxation in the rural surrounding metropolitan areas which will function as recreational belts around cities. As this rural urbanization occurs fast-paced, it needs to be done sustainably and healthily, backed-up by pro-active policies so as to reduce inequalities among its composing communes and spread tourist flows equally throughout the entire rural area of the metropolitan belt. Rural development should bring about an expanding employment in in the suburban areas (Sykora and Ourednicek, 2007), also in the tourism sector. The tourism rural metropolitan development is possible due to a clustering of technical infrastructure facilities that lie at of the basis of most economic and social activities. The technical infrastructure in the rural OMA was surveyed for road, air, water accessibility, water sewage and Internet connection. For instance, the internet technology has proved to be a particularly good tool for consumers to communicate about social topics such as holidays and travel (Page, 2019). The results for this analysis showed a rather reduced score, the average for the entire rural OMA being of 11 points out of 30 allocated points, the average score being much negatively influenced by a very low score of the two newly entered communes ( 3 points) in the metropolitan area versus the other communes which most range above 10 points, indicating gaps in technical coverage. With a good transport and communication accessibility travel and holidaymaking speeds up, thus "linking transport, spatial structures and social effects" (Geurs et al., 2012, p. 7).

\section{METHODOLOGY}

In order to achieve this scientific research, we relied on the Methodology for assessing the tourist potential in the basic administrative-territorial units. According to it, the diagnosis of the tourist and technical infrastructure was made taking into account the following components:

- specific tourist infrastructure (i.e. tourist accommodation units; treatment facilities; conference rooms, exhibition centers, etc.; ski slopes and skiing cable facilities; entertainment facilities).

- technical infrastructure (accessibility to major transportation; sewage facilities; telecommunication coverage).

For each component specific to the two infrastructure categories existing at the level of each TAU which makes up the rural space of the OMA scoring points were granted according to the evaluation methodology. Thus, each commune accumulated a certain score depending on the concentration degree of the components specific to the tourist and technical infrastructure. Based on this score, it was possible to make a ranking of the TAUs highlighing which one is better equipped versus the other.

Furtheron, in order to achieve our goal, we did desktop reference documetation, based on the national and international literature. Field trips were also made to locate and quantify the main units that make up the tourist and technical infrastructure. For the analysis and interpretation of data obtained both from various statistical sources and from the field, the method of analysis and synthesis was applied and by the help of ArcGis Online we elaborated maps with the tourism and technical infrastructure outspread in the territory within the 11 metropolitan TAUs.

The elements of the tourist infrastructure can be found in an ArcGIS Online document, developed by the authors of this article, an application that allows the sharing of content with other people, both Romanian and other languages. The access to the information from the ArcGIS Online document can be made via the following link: https://dgtatamd.maps.arcgis.com/apps/webappviewer/index.html?id=e05528e7d74a47ad999b4698fc8e64ed.

\section{RESULTS AND DEBATES}

\section{Oradea Metropolitan Area - the characteristics of the tourist infrastructure}

The prosperity, the high economic and enhanced socio-cultural standard of the metropolitan area is also the result of its underlying activities in the field of tourism which, in turn, could not develop satisfactorily unless an adequate and diverse tourist infrastructure exists. 
In the OMA, two tourist spas from Sînmartin commune draw our attention, namely Băile Felix $^{1}$ and Băile $1 \mathrm{Mai}^{2}$ spas, their appearance and development being related to the presence of thermal waters and in their planning of the urbanization phenomenon trend is easily identified.

Regarding the tourist accommodation units (represented by hotels, motels, guesthouses, agritourism guesthouses, classified between 1-5 stars/flowers) from the OMA, there is an unequal spread, most of them being located in the two spas (Figure 1).

Sînmartin commune, through the presence of the two balneoclimatic spas, has a reputed tourist function. According to data from the Ministry of Tourism (updated in 06.11.2020) ${ }^{3}$, it holds 237 (93.3\%) of the total 254 accommodation units of the rural OMA (Figure 2) and concentrates 8656 (94.7\%) places for accommodation from a total of 9136 (Figure 3). Thus, the accommodation basis is very diversified, including 22 hotels, a 5 stars hotel with 262 beds accomodation acapacity, four 4 stars hotels ( 890 beds), twelve three stars' hotels ( 2102 beds) and five 2 stars hotels (1854 beds).

As can be seen, the 3 and 2 star hotels dominate, concentrating almost $80 \%$ of the accommodation hotel capacity. In fact, the entire accommodation basis in the rural metropolitan area is characterized by the dominance of 2 and 3 stars units (hotels, guesthouses, etc.) (Figure 4) in terms of comfort ranking categories (Figure 5). The other accommodation units in Sânmartin commune consist of motels, tourist and agrotourism guesthpuses, tourist villas, private villas with rooms for rent, etc. They amount to a total of 215 units, offering 3548 accommodation beds.

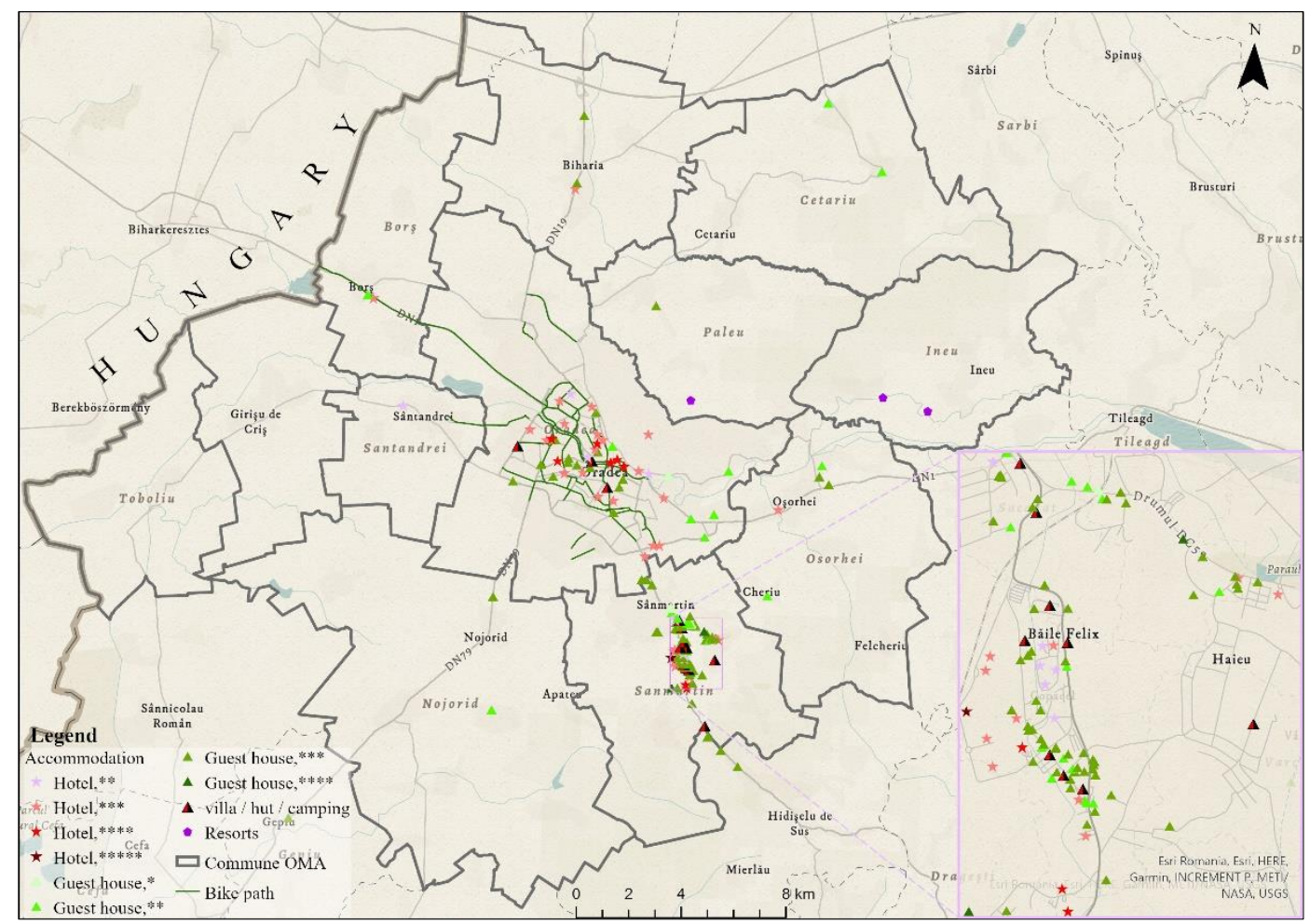

Figure 1. The OMA accommodation units typology

In the rest of the communes, the accommodation basis is much below the level of the two resorts, both in the number of accommodation units (17) and their category: one 3-star hotel with

\footnotetext{
${ }^{1}$ The greatest permanent spa of Romania

${ }^{2}$ Local-interest spa

${ }^{3}$ http://turism.gov.ro/web/autorizare-turism/
} 
146 beds (Borș commune), the others being motels or classified guesthpouses with 2-3 stars/flowers, but with few accommodation beds (1 unit with 16 beds in Borș locality, 5 units with 86 beds in Osorhei commune, two units with 72 beds in Biharia commune, one unit with 52 beds in Sîntandrei commune, two units with 61 beds in Ineu commune, three units with 30 beds in Nojorid commune, one unit with 11 beds in Cetariu commune, one unit with 6 beds in Paleu commune, 0 units in Girișu de Criş and Toboliu communes).

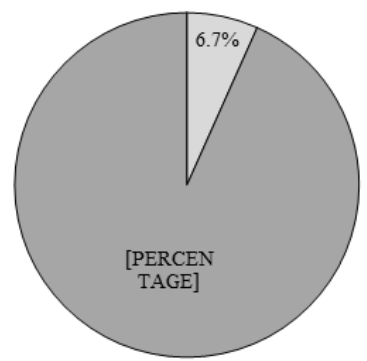

口Other communes of the O.M.A. 口Commune Sânmartin

Figure 2. Weigth of accommodation units in Sînmartin and the other ommunes of the OMA (November, 2020)

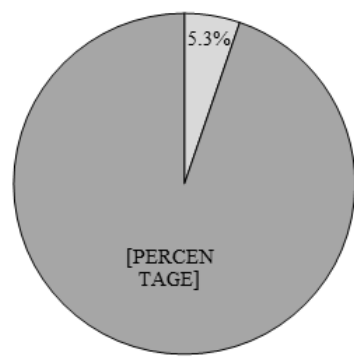

口Other communes of the O.M.A. 口Commune Sânmartin

Figure 3. Weight of beds in Sînmartin and the other ommunes of the OMA

(November, 2020)

Accommodation capacity

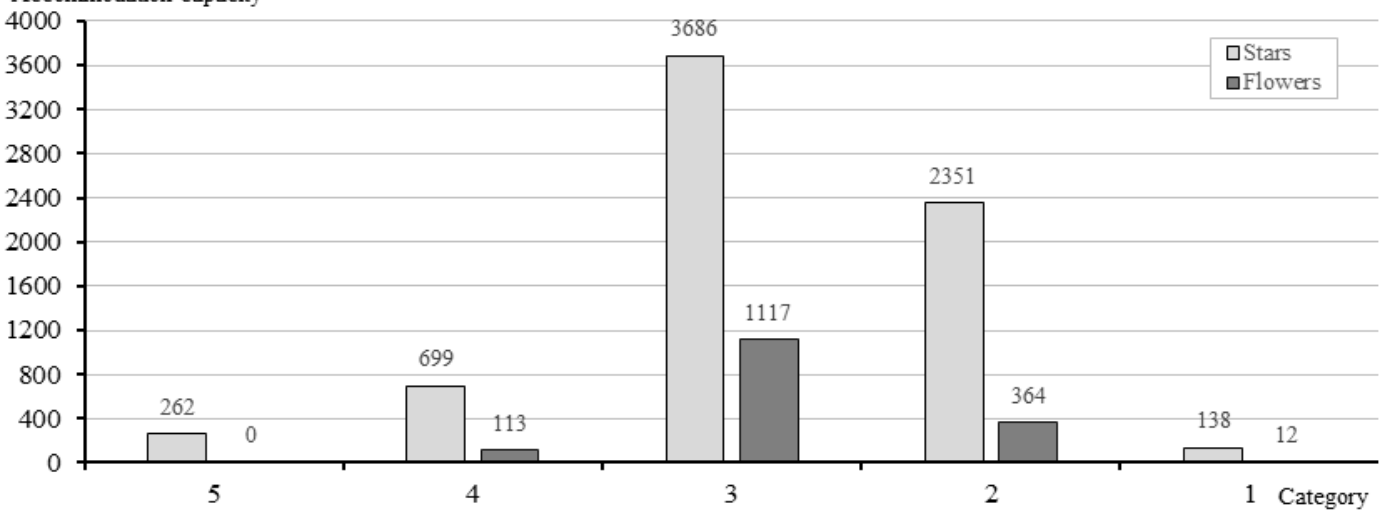

Figure 4. Accommodation capacity in OMA on comfort ranking (June, 2019)

(Source: http://turism.gov.ro/web/autorizare-turism/)

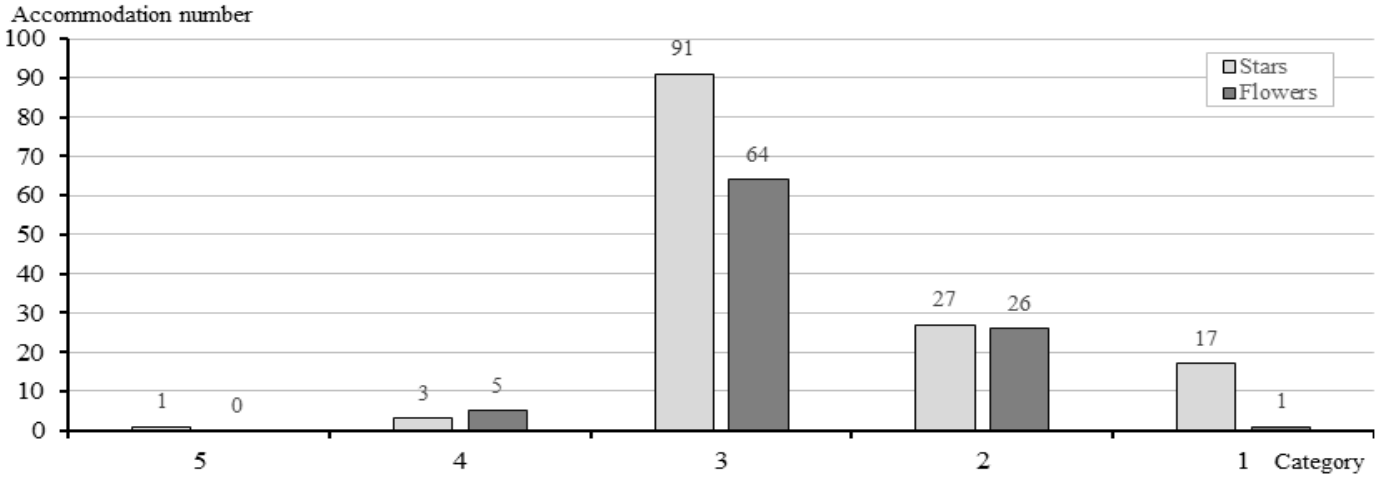

Figure 5. The rural OMA accommodation units ranking on comfor categories (June, 2019)

(Source: http://turism.gov.ro/web/autorizare-turism/) 
On the other hand, in the rural OMA we can find the category of tourist complexes/ensembles formed by accommodation units, restaurants, terraces, leisure lakes, located on the banks of man-made lake reservoirs (Fishermen's Inn from Paleu, Magnolia from Biharia, Camelot from Husasău de Criş, King's Land from Ineu, Dodo from Sîntandrei).

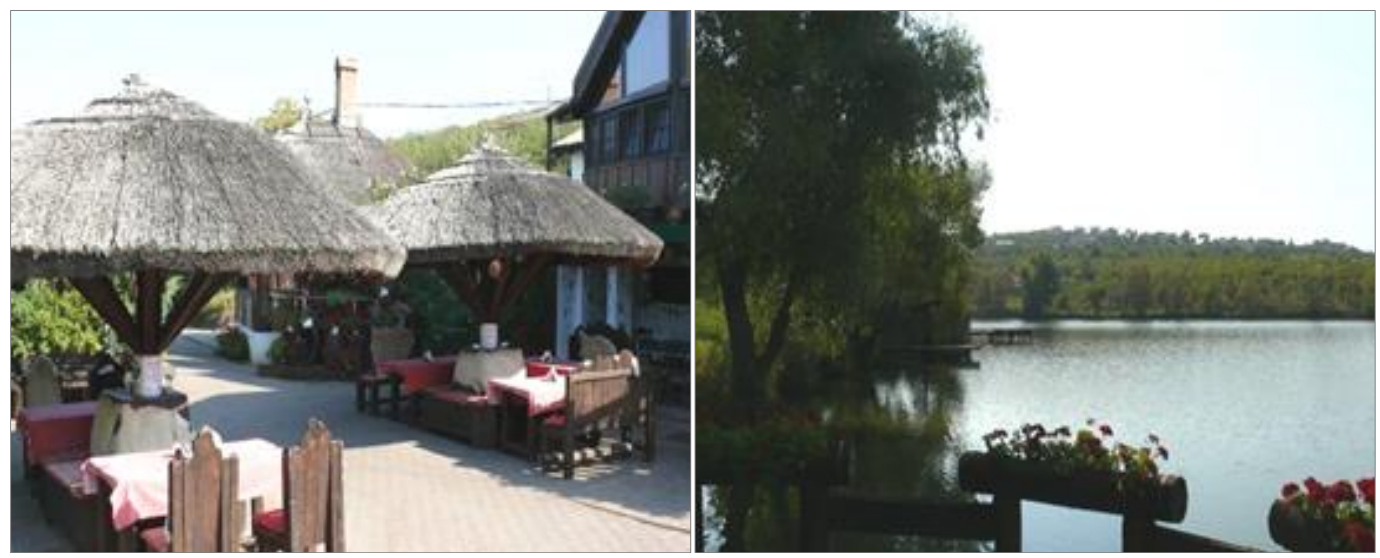

Figure 6. The tourist complex Hanul Pescarilor/Fishermen's Inn of Paleu

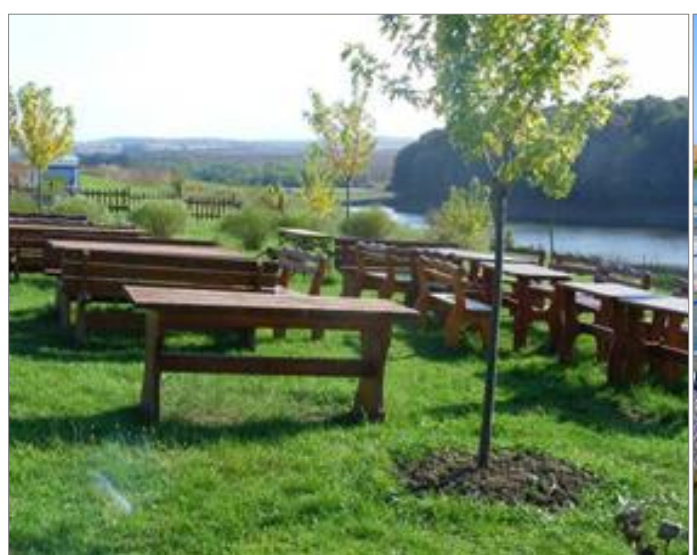

On the bank of the Şişterea lake

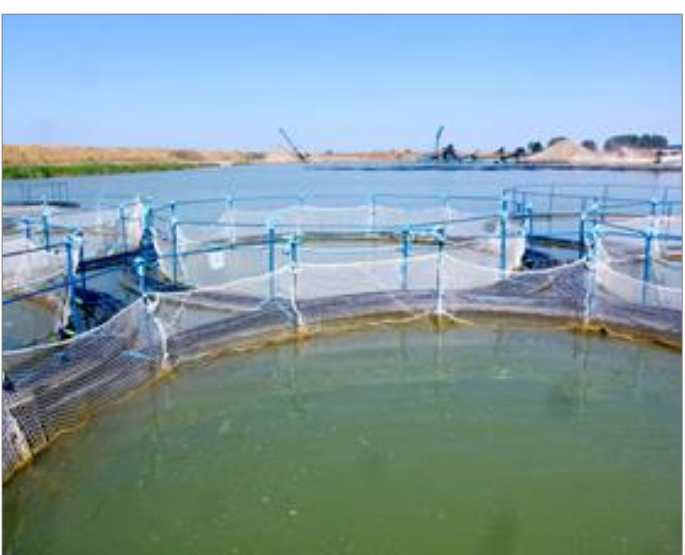

The fishing pond nets of Santău Mic ${ }^{4}$

Figure 7. Reservoirs with complex functions

Spa treatment equipments and entertainment facilities are also concentrated in the 1 Mai and Băile Felix spas. Here you will find a wide range of facilities and means for health and treatment, especially in the two medical recovery hospitals (for adults in Băile Felix spa, for children in the 1 Mai spa), but hotels also have their own treatment wellness and spa basis. To these numerous outdoor / indoor pools add up (at the hotels International, Mureş, Crişana, Termal, Nufărul, Ceres), swimming pools (Apollo-Felix, Padis, Venus, the wave pool) and aquaparks (Aqua President, Felixarium, Perla).

In the other localities from the OMA, it is not possible to talk about this category of tourist infrastructure (in the village of Livada of the Nojorid commune there is a swimming pool that works with thermal water, but it is currently closed).

Nonetheless in some villages we can find small lake accumulations with complex functions (Tătar et al., 2018) and gravel ponds in the meadow of Crisul Repede river that have some

\footnotetext{
${ }^{4}$ https://www.gavella.ro/index.php?idmenu=4
} 
facilities for fishing (cash and release), as well as picnic areas. To these two small fish farms are added (in the communes of Sîntandrei and Borş).

Another interesting entertainment element that is very suitable for ecotourism is represented by 5 herds of horses (three in Sânmartin, one in Paleu and one in Ineu communes).

Furthermore within the King's Land tourist complex of Ineu there is an aerodrome for light aircraft, gliders, motor gliders and a golf course. Within this tourist complex leisure and fun activities can be complemented by a series of cycling demonstrations and events (http://kingslandineu.com/). The slopes with different difficulty levels are accessible for both beginners and the most experienced.

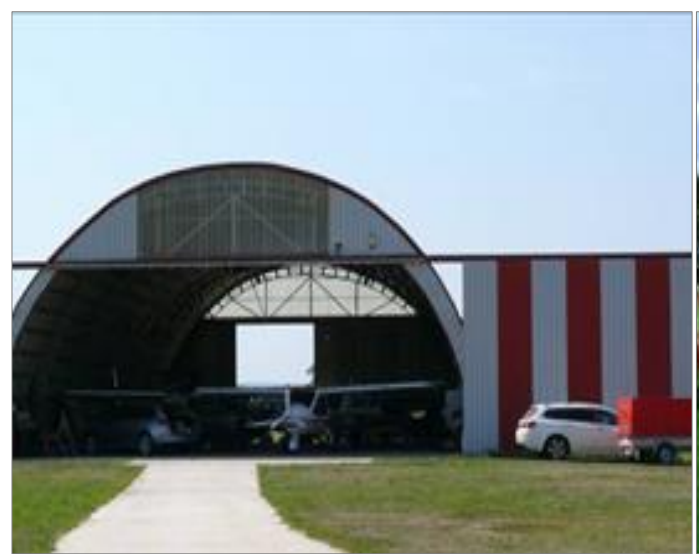

Hangar for light aircraft in Ineu

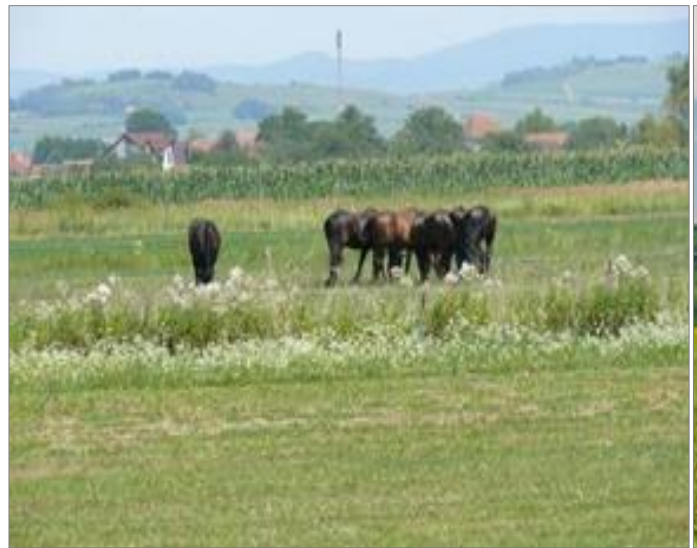

A few horses from the herd of Ineu

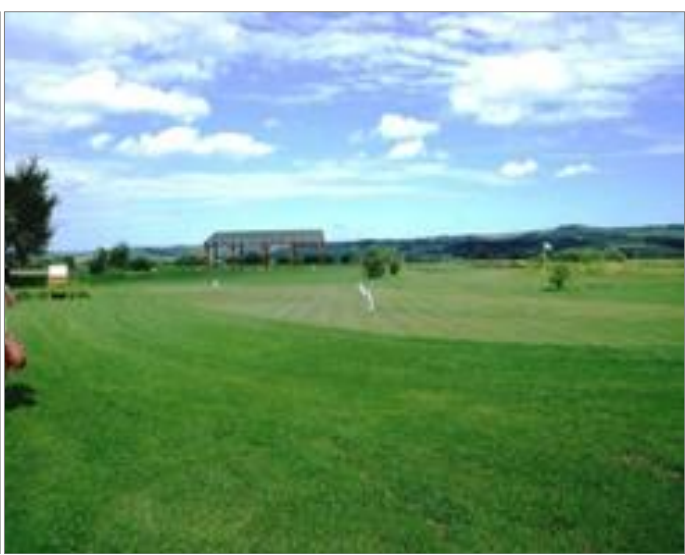

Golf course of Ineu

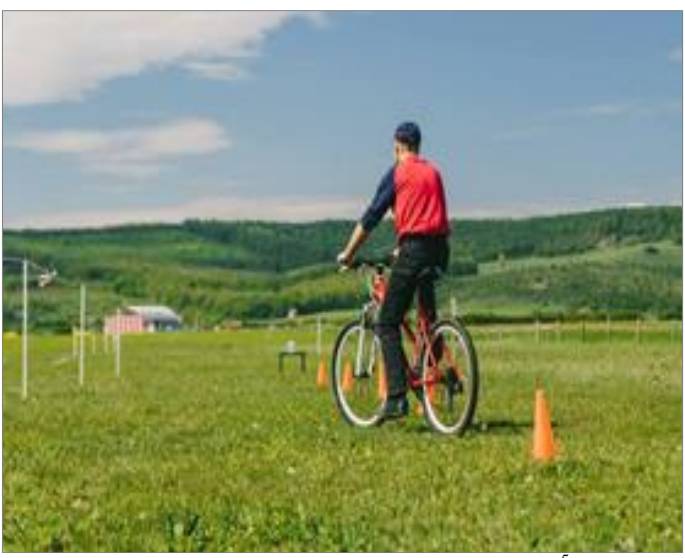

Cycling race at Kingsland Country Club $^{5}$

Figure 8. Entertainment opportunities in King's Land (Ineu commune)

The restoration facilities (restaurants, pizzerias, terraces) are well represented in the spas of Sînmartin commune, but we also find them in other locations of OMA, either in next to accommodation units or as independent units (in the villages of Biharia, Oşorhei, Cheresig).

By the help of European funds, the development of tourist information and promotion centers in the communes of Cetariu and Sînmartin (Băile Felix) was planned.

Accessibility to any tourist attraction in rural OMA is facilitated by a network of communication routes such as national / European roads (E-60 Borș-Oradea-Oșorhei-Cluj-Napoca; DN 76 Oradea-Sânmartin-Deva, DN 79 Oradea-Nojorid-Arad; DN 19 Oradea-Biharia -Satu 
Mare), county and communal roads, with an average density of $1.27 \mathrm{~km} / \mathrm{km}^{2}$. With few exceptions (there are several unpaved roads), they have a good asphalt cover. The fastest way is by car, but there is also public transport with the help of regular bus or minibus lines of some private companies that connect Oradea with each commune in the metropolitan area. The bike paths, represented with green on the map (Figure 9) feature disparate sectors all converging toward Oradea city, a future planning should also connect all these bike lanes into a cicular belt to connect all the metropolitan communes.

In the commune of Nojord, $4 \mathrm{~km}$ from the city of Oradea, there is the Oradea International Airport (charter flights), and in the Oradea railway station there are train connections from all over the country and from abroad (Austria, Hungary).

Still in the category of transport services, we find rent-a-car services (in Oradea), internet access and banking systems (several banks have ATMs in the commune centers). For example, Banca Transilvania has ATMs in the localities: Sânmartin, Băile Felix, Cordău, Oșorhei (Fughiu), Biharia, Cauaceu, BRD in the localities: Băile Felix, Borș (Sântion), CEC Bank in Băile Felix.

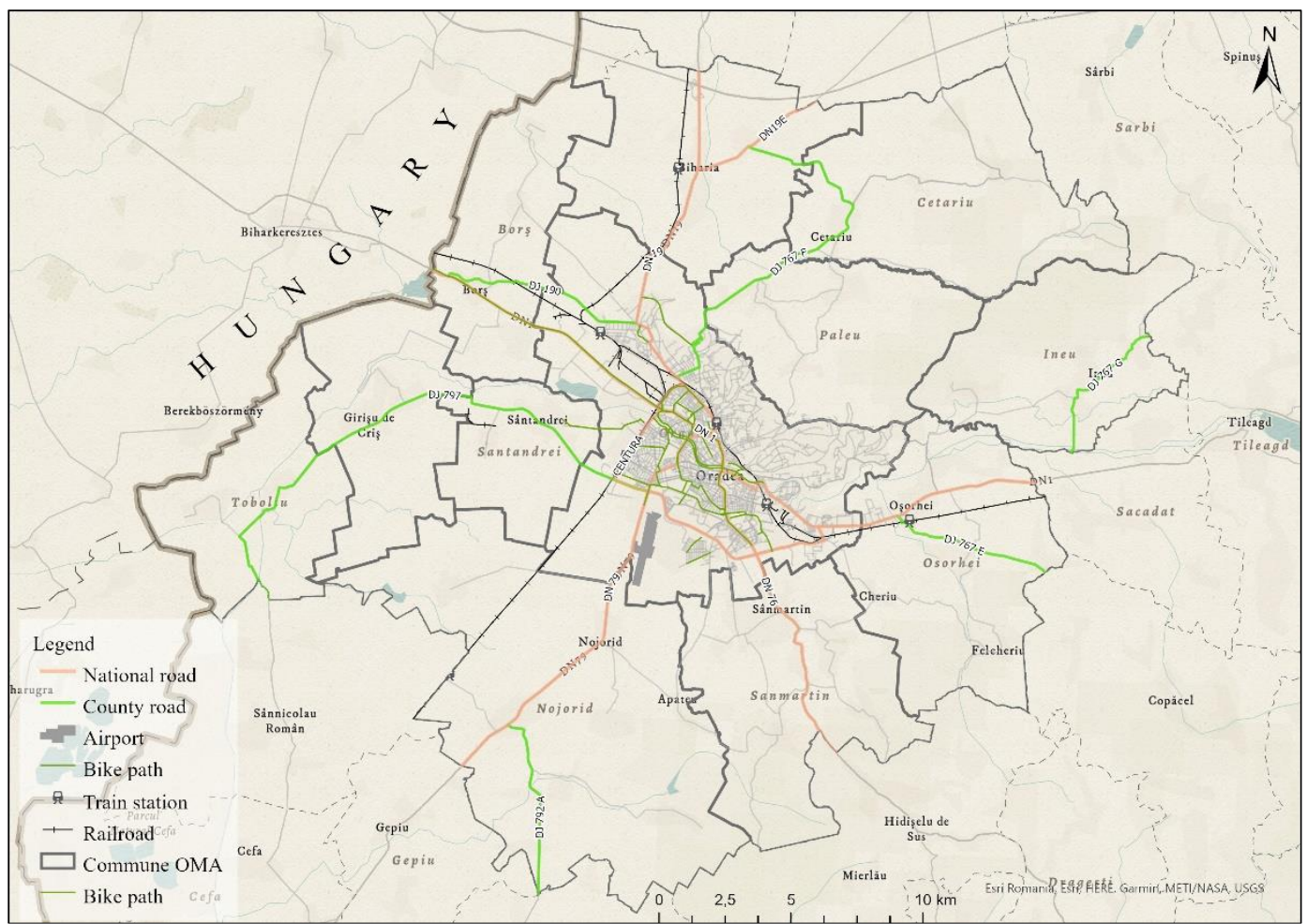

Figure 9. The accessibility transportation network to the tourist attractions of the OMA

\section{Survey of the specific tourist and technical infrastructure}

According to the Methodology for assessing the tourist potential in the basic administrative-territorial units (TAUs) for the Specific tourist infrastructure, out of 100 points, 20 were allocated to it and distributed as follows: tourist reception structures with accommodation functions 7 points; treatment facilities, 5 points; conference rooms; exhibition centers 6 points; ski slopes; cable transport facilities 1 point; other leisure facilities 1 point.

On the OMA territory the the score distribution is the following (Table 1):

As can be seen in Table 1 and illustrated in Figure 10, the highest score related to the tourist infrastructure is achieved by the presence of accommodation units, the maximum score 
going to Sânmartin commune, to which the two spas brought a special contribution. The other TAUs, due to reduced accommodation facilities, received minimum scores. Unfortunately, the rest of the components that make up the tourist infrastructure (treatment facilities, conference rooms, cable transport facilities, etc.), with the exception of Sânmartin TAU, are almost non-existent. Therefore, the specific tourism infrastructure in the OMA features an obvious disproportion, its greatest concentration and diversification being present in the Sânmartin TAU which concentrates 60\% (18 points) of the score calculated at the level of this indicator for the entire rural OMA (30 points). The remaining $40 \%$ of the score is divided between the other 10 communes, returning an average of 1.2 points/commune, given that two communes (Girișu de Criș and Toboliu) do not have such facilities.

Table 1. The specific tourist infrastructure of the OMA

\begin{tabular}{|c|c|c|c|c|c|c|}
\hline $\begin{array}{l}\text { Name of } \\
\text { commune }\end{array}$ & \begin{tabular}{|c|} 
Accommodation \\
units \\
(max 7 points) \\
(hotels - 5 points; \\
(agri)guesthouses - 1point; \\
1 point - other types of \\
units)
\end{tabular} & $\begin{array}{c}\text { Treatment } \\
\text { facilities } \\
\text { (max } 5 \text { points) }\end{array}$ & $\begin{array}{c}\text { Conference } \\
\text { rooms, exhibts } \\
\text { centres } \\
\text { (max } 6 \text { points) }\end{array}$ & $\begin{array}{c}\text { Ski slopes, cable } \\
\text { transportation (max } \\
1 \text { point) }\end{array}$ & \begin{tabular}{|c|} 
Other \\
entertainment \\
facilities \\
$\begin{array}{c}\text { (pool, aquapark, equestrian } \\
\text { centre, leisure water-based } \\
\text { activities, fishing) } \\
\text { (max 1point) }\end{array}$ \\
\end{tabular} & $\begin{array}{c}\text { Total } \\
\text { commune }\end{array}$ \\
\hline Biharia & 1 & - & - & - & 1 & 2 \\
\hline Borș & 2 & - & - & - & - & 2 \\
\hline Cetariu & 1 & - & - & - & - & 1 \\
\hline Girișu de Criș & - & - & - & - & - & - \\
\hline Ineu & 1 & - & - & - & 1 & 2 \\
\hline Nojorid & 1 & - & - & - & - & 1 \\
\hline Oșorhei & 1 & - & - & - & - & 1 \\
\hline Paleu & 1 & - & - & - & 1 & 2 \\
\hline Sînmartin & 7 & 5 & 5 & - & 1 & 18 \\
\hline Sîntandrei & 1 & & & - & - & 1 \\
\hline Toboliu & - & - & - & - & - & - \\
\hline \begin{tabular}{|c|} 
Total rural \\
OMA
\end{tabular} & 16 & 5 & 5 & - & 4 & 30 \\
\hline $\begin{array}{c}\text { Rural average } \\
\text { of OMA }\end{array}$ & 1.45 & 0.45 & 0.45 & 0 & 0.37 & 2.72 \\
\hline
\end{tabular}

Table 2. Technical infrastructure in OMA

\begin{tabular}{|l|c|c|c|c|c|c|c|c|}
\hline $\begin{array}{c}\text { Name of } \\
\text { commune }\end{array}$ & $\begin{array}{c}\text { Access to } \\
\text { port } \\
\text { (max 1 point) }\end{array}$ & $\begin{array}{c}\text { Access to } \\
\text { national/ } \\
\text { international } \\
\text { airport } \\
\text { (max 5 points) }\end{array}$ & $\begin{array}{c}\text { Access to } \\
\text { European } \\
\text { road } \\
\text { (max 5 points) }\end{array}$ & $\begin{array}{c}\text { Access to } \\
\text { national } \\
\text { road/railway } \\
\text { (max 5 points) }\end{array}$ & $\begin{array}{c}\text { Water, } \\
\text { Sewage and } \\
\text { tormwater } \\
\text { network } \\
\text { (max 5 points) }\end{array}$ & $\begin{array}{c}\text { Natural gas } \\
\text { supply } \\
\text { (max 4 points) }\end{array}$ & $\begin{array}{c}\text { GSM } \\
\text { coverage/lan } \\
\text { dline } \\
\text { (max 5 points) }\end{array}$ & $\begin{array}{c}\text { Total } \\
\text { commune }\end{array}$ \\
\hline Biharia & - & - & 5 & 2.5 & 5 & 2 & 3 & 17.5 \\
\hline Borș & - & - & 5 & 2.5 & 5 & 4 & 3 & 19.5 \\
\hline Cetariu & - & - & - & - & 2.5 & - & 3 & 5.5 \\
\hline Girișu de Criș & - & - & - & - & - & - & 3 & 3 \\
\hline Ineu & - & - & - & - & 2.5 & - & 3 & 5.5 \\
\hline Nojorid & - & 5 & 5 & 2.5 & 3.5 & - & 3 & 19 \\
\hline Oșorhei & - & - & 5 & 5 & 2.5 & - & 3 & 15.5 \\
\hline Paleu & - & - & - & - & 5 & - & 3 & 8 \\
\hline Sînmartin & - & - & 5 & 2.5 & 5 & - & 3 & 15.5 \\
\hline Sîntandrei & - & - & - & - & 2.5 & 4 & 3 & 9.5 \\
\hline Toboliu & - & - & - & - & - & - & 3 & 3 \\
\hline $\begin{array}{c}\text { OMA total } \\
\text { rural }\end{array}$ & - & $\mathbf{5}$ & $\mathbf{2 5}$ & $\mathbf{1 5}$ & $\mathbf{3 3 . 5}$ & $\mathbf{1 0}$ & $\mathbf{3 3}$ & $\mathbf{1 2 1 . 5}$ \\
\hline $\begin{array}{c}\text { OMA rural } \\
\text { average }\end{array}$ & - & $\mathbf{0 . 4 5}$ & $\mathbf{2 . 3}$ & $\mathbf{1 . 3}$ & $\mathbf{3 . 0 5}$ & $\mathbf{0 . 9}$ & $\mathbf{3}$ & $\mathbf{1 1}$ \\
\hline
\end{tabular}

For the criterion Technical infrastructure, out of a total of 100 points, 30 were allocated, distributed as follows: direct access to major transport infrastructure (16 points), provision of public communal management services - urban infrastructure ( 9 points) and availability of 
electronic communications services - telecommunications infrastructure ( 5 points). In the analysis of the major transport infrastructure, the TAU's access to the port was taken into account (max. 1 point), the access to the international / national airport - max. 5 points, access to European road (E) - max. 5 points, access to national road / railway - max 5 points. For the urban infrastructure out of the 9 granted points, a maximum of 5 points are offered to TAUs that have a water supply, sewage and stormwater networks and a maximum of 4 points for gas supply, as well as the telecommunications coverage has a maximum of 5 points (Table 2).

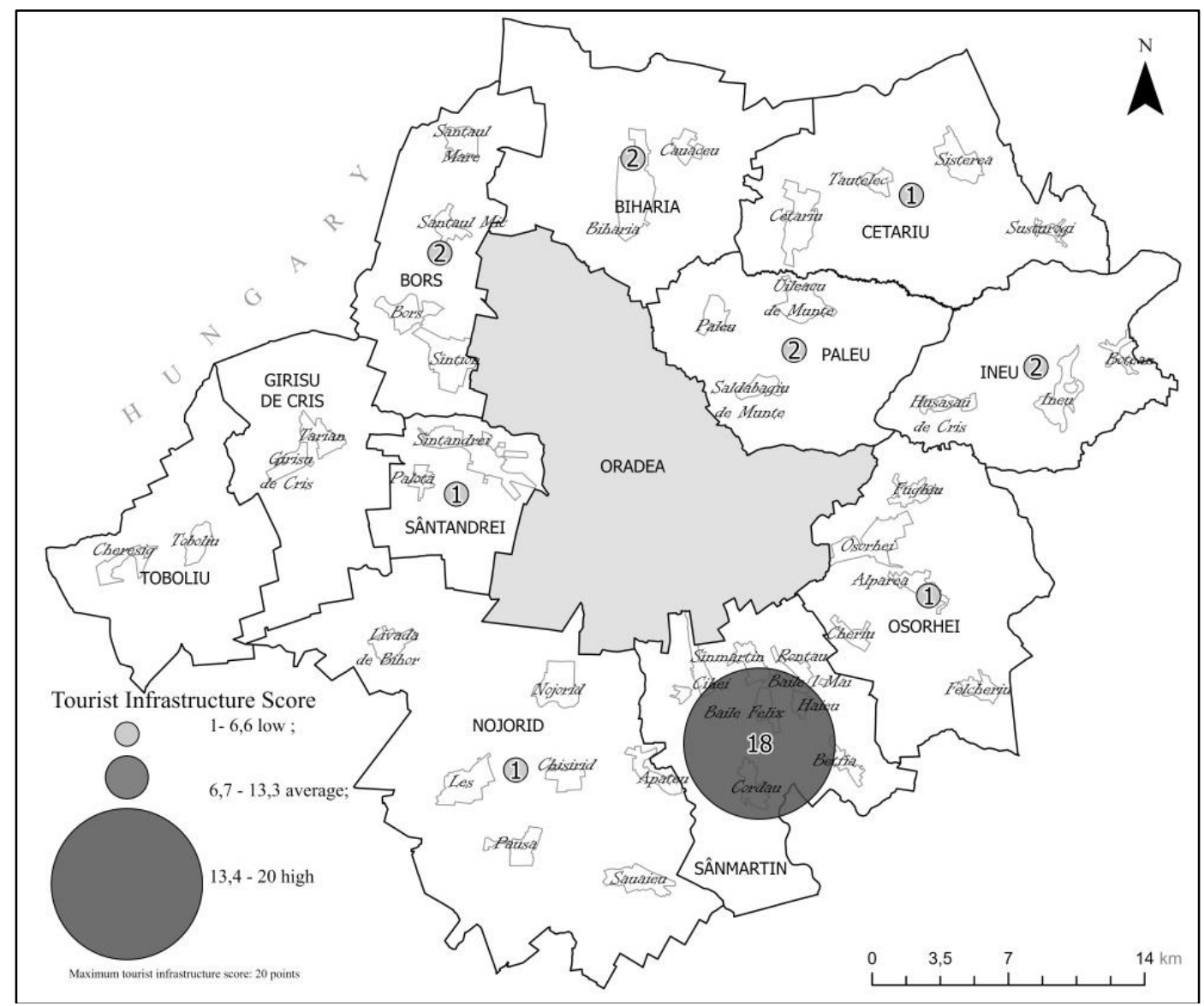

Figure 10. Specific tourism infrastructure score

Following the analysis of the technical infrastructure in the OMA, based on the mentioned indicators it can be seen that the telecommunications network and especially the mobile one with GSM coverage is present in all TAUs pertaining to the metropolitan area, thus increasing the degree of endowment and comfort.

What differentiates the localities of the metropolitan area is the different degree to which some of them have or do not have access to the various networks of roads or to the municipal infrastructure. From this point of view, the Borss TAU stands out, which, benefiting from an advantageous position, has both transport infrastructure (being crossed by the national/European road DN1/E 60), and the municipal one, respectively the water and natural gas supply. The Nojorid TAU.stands out through the transport infrastructure with access to the national/European road DN 79/E 671, but also through the proximity to the (inter) national airport in Oradea. The Biharia TAU has a technical infrastructure very similar to Borș commune, but the difference is 
made by the partial natural gas supply (for now, only at the level of the commune center). Furthermore, with identical scores, the communes of Sâmnartin and Oșorhei stand out, which, unlike the previous TAUs, lack the methane gas supply network.

\section{CONCLUSIONS}

The existing tourist and technical infrastructure at the level of the rural space within the OMA shows obvious disproportions at the level of each TAU. These gaps are somewhat accountable, given that two of the famous spas of national and local interest in Romania have developed here (Băile Felix and Băile 1 Mai spas), which makes Sânmartin TAU to stand out from the rest of the metropolitan communes, at least in terms of tourist infrastructure concentration.

We did not find the same thing at the level of technical infrastructure, as it is more equitably concentrated at the level of the TAU. First of all, the water supply and sewerage infrastructure stand out, followed by the communications infrastructure that obtained the most points (33.5, respectively 33$)$, these being present in almost every commune.

Other components that stand out depending on the accumulated score are represented by the access to a European road (25 points), to the national road (15 points) and to the gas supply (10 points). Access to the european/national road is easy only for 5 communes (Biharia, Borș, Nojorid, Oșorhei with railway access - and Sânmartin), and the endowments with methane gas, although long awaited in the metropolitan countryside, are still expected. Only three communes have this advantage: Borș, Sântandrei and in Biharia only the commune center is supplied with methane gas.

On the opposite end, there are two communes (Girișu de Criș and Toboliu) where the tourist and technical infrastructure is poorly represented, perhaps due to the fact that they joined the metropolitan area later (in 2007), Toboliu commune resulting from the detachment of Toboliu villages and Cheresig from Girișu de Criș commune. Perhaps the peripheral position was a disadvantage, but certainly the development strategies of these communes will focus on the two categories of infrastructure.

\section{REFERENCES}

Baias, S., Blaga, L., Dehoorne, O., Grama, V., Gozner, M., Herman, G., Ilieş, D.C., Ilieş, A., Josan, I., Morar, C. (2010). Băile Felix-Băile 1 Mai-Betfia (judeţul Bihor), Harta geoturistică, Editura Universităţii din Oradea.

Bucur, L. (2012). Studiu geografic al Zonei Metropolitane Oradea prin Sisteme Informaţionale Geografice, Editura Muzeului Ţării Crişurilor, Oradea.

Dincă, I. (2008). The emergence of Oradea - Paleu - Cetariu - Şişterea axis for villeggiatura tourism. Asertion possibilities based on local resources, sight - seeings and initiatives. Geographical Forum - Geographical studies and environement protection research, 7, 167-177.

Dincă, I., Herman, G. V., \& Sztankovics, G. (2012). Descoperire prin ecoturism şi prin turism rural în Comuna Cetariu. Editura Universităţii din Oradea.

Dincă, I., Linc R., Tătar C., Nistor S., Staşac M., Bucur L. (2017), Surveying the Rural Resilience within the Oradea Hills Household Independent Cellar Landscape, Romania. in Modern Technologies for the 3 rd Millennium, EDlearning, published by Thomson Reuters - Philadelphia formerly Institute for Scientific Information ISI, Editografica s.r.l., Bologna (Italy), p. 13-22, ISBN 978-88-87729-41-2, http://www.edlearning.it/.

Fuschi, M., \& Evangelista, V. (2017). The Rural Tourism Challenge in Pescara's Hilly Landscape, Italy: Awareness, Integration, Sustainability. GeoJournal of Tourism and Geosites, 20(2), 272-281.

Geurs, K.T., Krizek, K.J., Reggiani, A. (2012). Accessibility analysis and transport planning: An Introduction. in Geurs K.T., Krizek K.J. and Reggiani A. (Eds), Edward Elgar Publishing Ldt.

Herman, G. V., \& Tătar, C. (2015). Trends and prospects in the evolution and dynamics of the Felix - 1 Mai Spas Tourist System. Analele Universităţii din Oradea, Seria Geografie, 24(1), 116-126.

Herman, G. V., Banto, N., Caciora, T., Ungureanu, M., Furdui, S., Grama, V., Buhaș, R., \& Buhaș, S., (2020). Tourism in Bihor County, Romania. Trends and Prospects. Folia Geographica, 62(2), 87-105.

Ilies, D.C., \& Josan I. (2009). The tourist complex spa Băile Felix-Băile 1 mai-personality, distinctiveness by protection versus depersonalization and nonspecific by globalization. conceptual and practical aspects regarding the role of the natural and anthropic setting in tourist fitting. GeoJournal of Tourism and Geosites, 2(4), 179-185.

Ilieş, D. C., Ilieş, A., Herman, G. V., Baias, Ş., \& Morar, C. (2011). Geotourist map of the Băile Felix-Băile 1 Mai-Betfia area (Bihor County, Romania). GeoJournal of Tourism and Geosites, 2(8), 219-226. 
Ilieş, D.C., Herman, G.V., Dehoorne, O., \& Măduța, F. (2013). The role of the importance of cyclotourism in the development of the Oradea Metropolitan area (Romania). GeoJournal of Tourism and Geosites, 12(2), 101-110.

Linc, R., Dincă, I., Nistor, St., Tătar, C., Bucur, L., Staşac, M., Stupariu, M. (2019). The Environmental Asset Of The Rural From Oradea Metropolitan Area (Romania). Analele Universităţii din Oradea, seria Geografie, 29(2), 1-17.

Page, S.J. (2019). Tourism Management. Routlege.

Staşac, M., \& Bucur, L. (2010). Geo-demographical changes in rural space of Oradea Metropolitan Area. Annals of the University of Craiova, Geography Series, 2, 223-332.

Sykora, L., Ourednicek, M. (2007). Sprawling post-communist metropolis: Commercial and residential suburbanization in Prague and Brno, the Czech Republic. Springer.

Tătar, C.F., Linc, R., Dincă, I., Bucur, L., Stupariu, M., Stasac, M., Nistor, S. (2018). Nature-based suburban leisure opportunities within the Oradea Metropolitan Area. Analele Universităţii din Oradea, Seria Geografie, 28(2), 269-281.

Weaver, D., \& Lawton, L. (2014). Tourism Management. Fifth Edition, Wiley.

*** (2011). Strategia de dezvoltare Locală a Zonei Metropolitane Oradea, www.zmo.ro

*** (2008). Study on Sustainable Urbanization in Metropolitan Regions. Halcrow Group Limited. Vineyard House.

http://kingslandineu.com/

http://turism.gov.ro/web/autorizare-turism/

https://zmo.ro/strategie

https://lege5.ro/gratuit/gezdcmrugu3a/evaluarea-reevaluarea-unitatilor-administrativ-teritoriale-uat-din-punctul-de-vedereal-concentrarii-resurselor-turistice-si-diagnosticarea-disfunctionalitatilor-privind-infrastructura-tehnica-situri?dp=geydcmrygmydqni

https://www.gavella.ro/index.php?idmenu=4

Submitted:

Octomber 10, 2020
Revised:

November 20, 2020
Accepted and published online December 08, 2020 